Jordanian University Students' Views on Emergency Online Learning during COVID-19

\title{
Jordanian University Students' Views on Emergency Online Learning during COVID-19
}

\author{
Saleh Al-Salman and Ahmad S. Haider \\ Applied Science Private University, Jordan
}

\begin{abstract}
The present study investigates the influence of digital technology, instructional and assessment quality, economic status and psychological state, and course type on Jordanian university students' attitudes towards online learning during the COVID-19 emergency transition to online learning. A survey of 4,037 undergraduate students representing four Jordanian public and private universities revealed that personal challenges (such as economic and psychological stress) decreased students' willingness to learn online in the future, while the quality of the online experience (including instructional and assessment quality) improved their attitudes towards learning online in the future. Students also believed that Arts \& Humanities courses were better suited for online teaching/learning than Sciences courses, a difference that persisted after controlling for personal challenges and the quality of the online learning experience.
\end{abstract}

Keywords: COVID-19, higher education, online learning, Jordan, attitudes, university students

Al-Salman, S. \& Haider, A.S. (2021). Jordanian university students' views on emergency online learning during COVID-19. Online Learning, 25(1), 286-302. https://doi.org/10.24059/olj.v25i1.2470

\section{Jordanian University Students' Views on Emergency Online Learning During COVID-19}

Research on the COVID-19 crisis in higher education has primarily focused on developed countries (Burgess \& Sievertsen, 2020; German Academic Exchange Service (DAAD), 2020; International Association of Universities, 2020; UNESCO, 2020; Upoalkpajor \& Upoalkpajor, 2020). Although several global studies have been conducted on the effect of COVID-19 on education, their focus and implications still tend to favor developed nations, with little attention given to developing countries in the Middle East (see Ahmad S Haider \& Saleh Al-Salman, 2020). In this study, we focus on Jordan, a Middle Eastern country that showed good potential for using the online learning model if the technological adequacy of Internet connections and bundles are fully secured. 
This study investigates the influence of digital technology, instructional and assessment quality, economic status/psychological state, and course type on Jordanian university students' attitudes towards online learning. The importance of the present study derives from its probing into a novel teaching-learning experience. Its assessment by the stakeholders, especially by students as the primary catalyst, may help reshape and revolutionize the higher education paradigm in Jordan. In this paper, we offer a unique lens investigating and uncovering the short-term effects and future implications of the sudden shift to the novel experiment of online learning on the Jordanian university students' academic, social, and psychological well-being. It also examines the students' views and reactions to the success or failure of the online teaching/learning experiment.

The structure of the rest of the paper comprises the following sections. The literature review section provides an overview of Jordanian higher education and online learning. The research methodology part describes the data collection process and sampling. The study then gives the results and research findings. The results will be subsequently discussed in relation to the theory, previous research, with conclusions and implications for further research.

\section{Review of Relevant Literature}

\section{Structure of Jordanian Higher Education}

Jordan is a country with limited resources; yet, it enjoys a regional reputation in education. With a population of 10 million strong, Jordan embraces 10 public universities, 24 private universities, and 50 community colleges (Ministry of Higher Education and Scientific Research (MoHESR), 2020). Jordanian universities provide a diverse spectrum of undergraduate and graduate academic programs, with programs in the arts and humanities, natural and applied sciences, medical and para-medical sciences, pharmacy, engineering, and other disciplines. All universities and community colleges in Jordan are governed by MoHESR and are regularly inspected by the Higher Education Accreditation Commission (HEAC), which was established in 2007 (Badran, 2014).

With regard to communication technology, Jordan has been known as a regional leader in developing and implementing Information and Communication Technology (ICT) applications. The Internet services in Jordan are available through several leading providers of ADSL and fiber optic, with reasonable prices. In recent years, ICT providers have partnered with the education sector to provide technical support and training to faculty members, staff, and students, and educational institutions have become open to the possibility that "computers and communication technology will change the whole institutional infrastructure and pattern of behavior within the education system" (Badran, 2014).

\section{Online Learning in Jordan}

While much of the developed world leaped online in the late 1990s and early 2000s, the Middle East and North Africa were more cautious in adopting the Internet (Human Rights Watch, 1999). Thus, although some instructors occasionally used some forms of e-learning tools during the $2000 \mathrm{~s}$, the traditional face-to-face teaching-learning model was the norm (Al-Shboul et al., 2013; Badran, 2014). The uptake of online learning across the Middle East was influenced by the general availability of technology and the Internet in each country (Hassan, 2008). For example, the United Arab Emirates (UAE) was among the first in the region to grant people access to the 
Internet, putting UAE institutions among the first to introduce e-learning in their educational system, while Jordan lagged behind them (Abbad et al., 2009; Ozkan \& Koseler, 2009; Selim, 2007).

Around 2010, Jordanian universities began to increase their usage of e-learning platforms such as LMS Moodle and Blackboard (Al-Shboul \& Alsmadi, 2010). The growing interest in moving towards using the e-learning tools in the teaching-learning process was stressed by Almarabeh (2014) who argued that in the next few years, Jordan would witness an accelerated move towards e-learning due to the fast pace of change and evolution in information and multimedia technology. Meanwhile, Jordanian scholars were encouraged to explore the possible implementation of the online learning model in Jordanian universities (Al-Shboul et al., 2013). However, Jordanian law also limited higher education programs to a maximum of $25 \%$ online learning (Wimpenny et al., 2018). During this period, research on online learning was sporadic, often taking the form of case studies. For example, in a study of Moodle usage at the University of Jordan, researchers found that students faced obstacles related to hardware resources and learning through the computer screen; otherwise, the students showed interest in moving ahead with the e-learning system (Almarabeh et al., 2014). Along the same lines, Majadlawi et al. (2014) reported that students at the University of Jordan are highly qualified to use the LMS Moodle as an e-learning platform, but noted that students in humanities faculties should improve their computer skills. Similarly, Al-Shboul et al. (2013) expressed satisfaction with the pace at which online learning was developing in Jordan but argued that Jordanian universities should provide institutions with adequate technical support and hardware infrastructure to meet the needs of faculty, staff, and students for teaching and training purposes (Al-Shboul et al., 2013). Al-Adwan and Smedley (2012) concurred that training and development are key factors that largely influenced stakeholders' attitudes towards engaging in e-learning supported by state-of-the-art digital technology.

During the period from 2015 to 2019, the adoption of online learning in Jordanian higher education remained relatively low (Al-Adwan et al., 2018). A report on e-learning in five public and private Jordanian universities suggested that most instructors were comfortable using online resources and open to increasing the typical level of online learning in most programs; however, some were skeptical that online learning would be effective in teaching practical skills (Wimpenny et al., 2018). However, the report noted a variety of challenges, including a lack of relevant online content in Arabic and unequal access to technology across institutions. Moreover, they noted that universities did not engage in systematic assessment of student experiences or satisfaction with online tools, and that instructors rarely checked with students to confirm they had appropriate digital skills and access to technology. Similar challenges, including technical issues resulting from low bandwidth or weak Internet connections, and the need to improve students' digital skills and provide them with the necessary digital tools, were reported by other scholars (see Alkhawaja \& Abd Halim, 2019; Canals \& Al-Rawashdeh, 2019).

These research attempts and case studies helped establish a foundation that enabled MoHESR's abrupt shift to the online learning model in response to the COVID-19 pandemic. However, students and faculty members may not have been fully prepared to communicate through fully automated and digitalized e-learning tools. Considering the changes brought by COVID-19, the need for crucial information on the Jordanian university students' views on the effectiveness of the online learning experiment is a top priority. To this end, the current study addresses the following questions: 
1) Do technology and Internet issues, students' economic status, and psychological states affect their attitudes towards the online teaching/learning model?

2) Which types of courses (Arts \& Humanities vs. Sciences) are better-suited for online teaching/learning than others? Which are less compatible with this model, and why?

\section{Methods}

The data of the present study were collected from the responses of 4037 undergraduate students of four Jordanian universities, two public and two private. Students from the Schools of Humanities and Sciences were asked to complete an electronic questionnaire to elicit their responses on the emergency online learning experience starting in March 2020 due to COVID-19. The questionnaire was sent via WhatsApp to the students registered in the summer term courses, i.e., one semester after shifting to online learning. The 4037 students' sample consisted of 2070 students in the Arts and Humanities (51\%) and 1967 in the Sciences (49\%). The school of Humanities includes: Faculty of Arts, Faculty of Business, Faculty of Sharia, Faculty of Educational Sciences, Faculty of Law, Faculty of Physical Education, Faculty of Foreign Languages, and Faculty of Archeology and Tourism. The School of Sciences includes: Faculty of Science, Faculty of Agriculture, Faculty of Engineering, Faculty of Information Technology, Faculty of Pharmacy, Faculty of Nursing, Faculty of Dentistry, and Faculty of Medicine.

The reason why these programs were chosen is that they represent the main bulk of the disciplines, which are quite popular among Jordanian university students. By choosing students from two different disciplines, namely Arts and Humanities vs. Sciences, we can survey students' reactions on the degree to which the online learning experiment was successful in each of the two disciplines. Compared to the total population of the four universities involved in the present study (approximately 41,000 ) students, the response rate of 4037 students was roughly $10 \%$. The discrete demographic information of the sample included information about students' gender and area of specialization.

\section{Research Instruments}

The researchers developed a questionnaire to elicit Jordanian university students' views on the emergency learning experiment imposed by COVID-19 during the second term of the academic year 2019-2020. The questionnaire has two sections. The first section aimed to collect demographic information about the gender of participants and area of specialization. The second section consisted of 6 main constructs, namely (1) Technology Adequacy, (2) Instructional Quality, (3) Assessment Quality, (4) Economic Stressors, (5) Psychological Stressors, and (6) Attitudes Towards the Future. In this part, students were asked to fill in a Likert-type questionnaire ranging from "strongly agree" (5) to "strongly disagree" (1) (see Appendix). The questionnaire was administered in Arabic, the official language in Jordan.

\section{Questionnaire Validity and Reliability}

Before developing the questionnaire, the researchers examined different questionnaires designed for similar purposes (see Bolliger \& Martin, 2018; Ahmad S Haider \& Saleh Al-Salman, 2020; Liaw et al., 2007; Roach \& Lemasters, 2006). The questionnaire was sent to a jury of three experts in the field for their feedback. The three-member jury team included an expert in survey design from the Department of Media and Communication, an IT statistician and data analyst, and 
a specialist in testing and measurement from the Faculty of Education. Recommendations provided by the jury were incorporated into the questionnaire.

The research questionnaire was distributed to a random sample of 100 students from four Jordanian universities to make sure that the 16 statements are clear and understandable. Necessary tests such as reliability analysis and correlation coefficients were conducted. Subsequently, the researchers made some modifications to the questionnaire before administering it.

To confirm the theorized structure of our subscales and to ensure that the subscales are internally reliable and reasonably distinguishable from one another, we first present the Cronbach's alpha for each subscale (Table 1) and then present the inter-correlations between the subscales (Table 2). A Cronbach's alpha test on a sample of 100 respondents was used to validate the reliability of the research instrument (Cronbach, 1951). Table 1 shows the results for the 16 statements of the questionnaire and how closely they are related in the six constructs.

\section{Table 1}

Reliability Analysis Through Cronbach Alpha Results

\begin{tabular}{lll}
\hline Construct & No. of Items & Cronbach's Alpha \\
\hline Technology Adequacy & 3 & 0.75 \\
Instructional Quality & 3 & 0.70 \\
Assessment Quality & 3 & 0.74 \\
Economic Stressors & 2 & 0.79 \\
Psychological Stressors & 2 & 0.77 \\
Attitudes towards the Future & 3 & 0.82 \\
All Variables & 16 & 0.76 \\
\hline
\end{tabular}

Table 1 indicates a high level of reliability and reflects a relatively high internal consistency. A reliability coefficient of 0.70 or higher is considered "acceptable" in social science research (Nunnally, 1978).

Based on the results above, a Bivariate (Pearson) Correlation was conducted, as Table 2 shows.

\section{Table 2}

Results of Pearson's Correlation

\begin{tabular}{lllll}
\hline & $\begin{array}{l}\text { Technology } \\
\text { Adequacy }\end{array}$ & $\begin{array}{l}\text { Instructional } \\
\text { Quality }\end{array}$ & $\begin{array}{l}\text { Assessment } \\
\text { Quality }\end{array}$ & $\begin{array}{l}\text { Economic } \\
\text { Stressors }\end{array}$ \\
\hline $\begin{array}{l}\text { Technology } \\
\text { Adequacy }\end{array}$ & 1 & & & \\
$\begin{array}{l}\text { Instructional } \\
\text { Quality } \\
\text { Assessment }\end{array}$ & $0.06^{*}$ & 1 & & \\
$\begin{array}{l}\text { Quality } \\
\text { Economic }\end{array}$ & $0.08^{* *}$ & $0.12^{* *}$ & 1 & 1 \\
$\begin{array}{l}\text { Stressors } \\
\text { Psychological }\end{array}$ & $-0.13^{* *}$ & $-0.13^{* *}$ & $-0.04^{*}$ & 1 \\
Stressors & $-0.28^{* *}$ & $0.06^{* *}$ & $-0.07^{* *}$ & $0.34^{* *}$ \\
\hline$* * p<0.01, * p<0.05$ & & &
\end{tabular}

Table 2 indicates mild correlations across the subscales, suggesting that they represent different constructs that can be considered separately in the analysis (Kendal \& Stuart, 1973). 


\section{Results}

The researchers compared the students' responses in the Arts \& Humanities with their counterparts in the Sciences, as Table 3 shows. The "\% agree" column provides the percentage of students who either "strongly agreed" or "agreed" with the item, while the "M (SE)" column provides the mean and standard error for that item. It is worth noting that "agreement" is a positive sign for some items, while it is a negative indicator in some others. In Table 3, items retain their original direction. Prior to calculating the subscale means for Technology Adequacy, Instructional Quality, Assessment Quality, and Attitudes Toward the Future (see Tables 1, 2, and 4), negative items were reverse-coded [R]. For the subscales of Economic Stressors and Psychological Stressors, negative items retained their original direction.

\section{Table 3}

"\% agree" and the mean and standard error " $M(S E)$ " for the questionnaire's item

\begin{tabular}{|c|c|c|c|c|c|}
\hline \multirow{2}{*}{ No. } & \multirow{2}{*}{ Item } & \multicolumn{2}{|c|}{ Arts \& Humanities } & \multicolumn{2}{|c|}{ Sciences } \\
\hline & & $\%$ Agree & M (SE) & $\%$ Agree & M (SE) \\
\hline \multicolumn{6}{|c|}{ Technology Adequacy } \\
\hline 1 & $\begin{array}{l}\text { The digital tools (mobile, laptop, or iPad) I use } \\
\text { in e-learning are of high quality. }\end{array}$ & $50 \%$ & $3.30(0.03)$ & $59 \%$ & $3.42(0.03)$ \\
\hline 2 & $\begin{array}{l}\text { I faced some technical problems in the online } \\
\text { lectures last semester due to Internet connection } \\
\text { issues. [R] }\end{array}$ & $59 \%$ & $3.46(0.03)$ & $25 \%$ & $1.49(0.02)$ \\
\hline 3 & $\begin{array}{l}\text { I encountered technical problems while } \\
\text { submitting exams electronically. [R] }\end{array}$ & $53 \%$ & $3.37(0.03)$ & $74 \%$ & $3.93(0.03)$ \\
\hline \multicolumn{6}{|c|}{ Instructional Quality } \\
\hline 4 & $\begin{array}{l}\text { In conducting online lectures, instructors use } \\
\text { digital e-learning tools effectively. }\end{array}$ & $55 \%$ & $3.52(0.03)$ & $43 \%$ & $3.66(0.02)$ \\
\hline 5 & $\begin{array}{l}\text { I believe that the course objectives and learning } \\
\text { outcomes have been achieved through distance } \\
\text { learning with the same degree of effectiveness } \\
\text { and efficiency as in face-to-face education. }\end{array}$ & $65 \%$ & $3.58(0.03)$ & $25 \%$ & $2.57(0.03)$ \\
\hline 6 & $\begin{array}{l}\text { Some components of the course material are not } \\
\text { compatible with distance learning methods. [R] }\end{array}$ & $36 \%$ & $2.91(0.03)$ & $72 \%$ & $3.91(0.02)$ \\
\hline \multicolumn{6}{|c|}{ Assessment Quality } \\
\hline 7 & $\begin{array}{l}\text { The methods of evaluation during the last } \\
\text { semester were fair and appropriate to the e- } \\
\text { learning environment and the nature of the } \\
\text { subject. }\end{array}$ & $48 \%$ & $3.29(0.03)$ & $30 \%$ & $2.80(0.03)$ \\
\hline 8 & $\begin{array}{l}\text { Holding exams for subjects of practical nature } \\
\text { must take place on campus. [R] }\end{array}$ & $53 \%$ & $3.57(0.02)$ & $70 \%$ & $3.84(0.03)$ \\
\hline 9 & $\begin{array}{l}\text { Some course materials need their own special } \\
\text { assessment tools. }\end{array}$ & $50 \%$ & $3.38(0.03)$ & $65 \%$ & $3.71(0.03)$ \\
\hline
\end{tabular}




\begin{tabular}{|c|c|c|c|c|c|}
\hline \multirow[b]{2}{*}{ No. } & \multirow[b]{2}{*}{ Item } & \multicolumn{2}{|c|}{ Arts \& Humanities } & \multicolumn{2}{|c|}{ Sciences } \\
\hline & & $\%$ Agree & M (SE) & $\%$ Agree & M (SE) \\
\hline \multicolumn{6}{|c|}{ Economic Stressors } \\
\hline 10 & $\begin{array}{l}\text { The e-learning experiment forced me to buy new } \\
\text { digital devices and Internet connection. }\end{array}$ & $57 \%$ & $3.47(0.03)$ & $59 \%$ & $3.56(0.03)$ \\
\hline 11 & $\begin{array}{l}\text { The economic situation makes it difficult for me } \\
\text { to secure the required e-learning tools. }\end{array}$ & $53 \%$ & $3.26(0.03)$ & $54 \%$ & $3.39(0.03)$ \\
\hline \multicolumn{6}{|c|}{ Psychological Stressors } \\
\hline 12 & $\begin{array}{l}\text { Measures of lockdown, closures, and quarantine, } \\
\text { brought by COVID-19 caused students' stress, } \\
\text { frustration, and depression. }\end{array}$ & $63 \%$ & $3.73(0.03)$ & $61 \%$ & $3.72(0.03)$ \\
\hline 13 & $\begin{array}{l}\text { Prolonged use of e-learning tools leads to } \\
\text { boredom, nervousness, and stress, which } \\
\text { negatively affected my academic performance. }\end{array}$ & $46 \%$ & $3.16(0.03)$ & $64 \%$ & $3.76(0.03)$ \\
\hline \multicolumn{6}{|c|}{ Attitudes Towards the Future } \\
\hline 14 & I would like to take online courses in the future. & $49 \%$ & $3.31(0.03)$ & $40 \%$ & $3.13(0.03)$ \\
\hline 15 & $\begin{array}{l}\text { I recommend using e-learning as an alternative } \\
\text { to traditional education. }\end{array}$ & $42 \%$ & $2.96(0.03)$ & $28 \%$ & $2.65(0.03)$ \\
\hline 16 & $\begin{array}{l}\text { I suggest transitioning to the blended- learning } \\
\text { model first before shifting completely to online } \\
\text { learning. [R] }\end{array}$ & $40 \%$ & $3.25(0.03)$ & $67 \%$ & $3.72(0.03)$ \\
\hline
\end{tabular}

[R] Reverse-coded statements, (SE) standard error of the mean.

Items 1 through 3 of the questionnaire aimed to collect responses about the digital tools students are using, Internet quality, and technical problems. While the Sciences students seemed to have fewer general challenges with technology in general, they encountered major technology challenges when submitting exams. This might be due to the nature of the materials, which sometimes require drawing charts and inserting particular symbols. Thus despite Science students' generally positive responses to items 1 and 2, their negative responses to item 3 tended to drag their overall assessment of technology adequacy below that of Humanities students.

Students' responses to items 4 through 6 aimed to collect feedback about the instructors' technical skills and online learning efficiency and their effect on achieving the course objectives and outcomes. When responding to item 5, the results showed that $65 \%$ of the students in the Arts \& Humanities agreed that the course objectives and learning outcomes in online learning could be achieved as effectively and efficiently as in the face-to-face model. Conversely, only $25 \%$ of the students in the Sciences agreed with the statement. This is confirmed by the students' responses to item 6 , where $72 \%$ and $36 \%$ of the students in the Sciences and Humanities, respectively, were in agreement with the statement which reads "some components of the course material are not compatible with distance learning methods."

Items 7 through 9 aimed to determine whether the online assessment methods are as efficient as the traditional ones. In response to item 7 , the results showed that $48 \%$ of the students in the Humanities and only $30 \%$ in the Sciences agreed that the methods of evaluation during the March 2020 e-learning experiment were fair and appropriate. This is confirmed in the responses to items 8 and 9 , where $70 \%$ and $53 \%$ in the Sciences and Humanities, respectively, believed that 
exams for subjects of practical nature should take place on campus. Similarly, $65 \%$ of the students in the Sciences and 50\% in the Humanities agreed that some course materials need their own special assessment tools.

Items 10 through 13 aimed to examine whether COVID-19's e-learning experiment has affected the students' economic and psychological state. The results showed that the Science students' academic performance was more adversely affected by using e-learning tools for long hours than their counterparts in the Humanities. This negative impact and inconvenience may be attributed to the Science students' heavy exposure to the Internet to search for relevant materials to help them better understand lab experiments and practical applications in their areas of specialization in the absence of face-to-face interaction.

Items 14 through 16 aimed to elicit responses on the students' attitudes towards the online learning experience and if they recommend it as an alternative to the traditional learning model. Only $28 \%$ of the students in the Sciences supported a complete shift to online learning, and $67 \%$ of them suggested transitioning to the blended learning model first. Their counterparts in the Arts \& Humanities seem to be more open to the idea, where $42 \%$ were in favor of using e-learning as an alternative to traditional education, with $40 \%$ of them opting for a blended learning transitional phase.

To test the differences between the students' responses in the Arts \& Humanities versus Sciences, we calculated the subscale means for each group and compared each subscale between the two groups using independent-samples t-tests (Table 4).

\section{Table 4}

Independent Sample T-Test

\begin{tabular}{llll}
\hline \multirow{2}{*}{ Factor } & \multicolumn{2}{c}{ Mean (SE) } & \multirow{2}{*}{ T value } \\
& Art \& Humanities & Sciences & \\
\hline Technology Adequacy & $3.38(0.02)$ & $2.95(0.02)$ & $16.78^{* * *}$ \\
Instructional Quality & $3.34(0.02)$ & $3.22(0.02)$ & $1.99^{*}$ \\
Assessment Quality & $3.41(0.02)$ & $3.29(0.02)$ & $8.67^{*}$ \\
Economic Stressors & $3.36(0.03)$ & $3.48(0.02)$ & $3.38^{* *}$ \\
Psychological Stressors & $3.45(0.02)$ & $3.74(0.02)$ & $9.30^{* * *}$ \\
Attitudes Towards Future & $3.17(0.02)$ & $2.99(0.02)$ & $7.18^{* *}$ \\
\hline
\end{tabular}

(SE) Standard error of mean, ${ }^{* * *} p<0.001,{ }^{* *} p<0.01,{ }^{*} p<0.05$

Table 4 shows that students in Arts \& Humanities were more satisfied than their counterparts in the Sciences about Technology Adequacy, Instructional Quality, and Assessment Quality in their online courses. Students in the Arts \& Humanities also reported lower levels of Economic Stressors and Psychological Stressors, and had more positive attitudes towards online learning in the future.

To explore how area of study and each subscale contributed to students' attitudes toward online learning in the future, we conducted a regression analysis predicting the subscale "Attitudes Toward the Future" with the predictors of area of study $(0=$ Sciences, $1=$ Arts \& Humanities $)$ and the subscale means for Technology Adequacy, Instructional Quality, Assessment Quality, 
Economic Stressors, and Psychological Stressors. The overall set of predictors explained over a third of the variance in the outcome, with $\mathrm{R}^{2}=0.34$.

\section{Table 5}

Results of Multiple Linear Regressions

\begin{tabular}{lll}
\hline Factor & B $(\mathbf{S E})$ & t value \\
\hline Area of Study & $0.12(0.03)$ & $10.29 * * *$ \\
Technology Adequacy & $0.17(0.02)$ & $11.83^{* * *}$ \\
Instructional Quality & $0.36(0.02)$ & $18.22 * * *$ \\
Assessment Quality & $0.16(0.02)$ & $10.72 * * *$ \\
Economic Stressors & $-0.10(0.01)$ & $-7.43 * * *$ \\
Psychological Stressors & $-0.12(0.02)$ & $-8.03 * * *$ \\
\hline$(S E)$ standard error, ${ }^{* * *} p<0.001, * * p<0.01,{ }^{*} p<0.05$
\end{tabular}

In Table 5, the beta values suggest that while each variable is a significant predictor of students' interest in taking online courses in the future, Instructional Quality is the strongest predictor, while Economic and Psychological Stressors were weaker predictors. After taking all the other predictors into account, the differences between Humanities and Sciences persisted; students in the Humanities remained more positive about taking online courses in the future compared to those in the Sciences.

\section{Discussion}

The present study addressed the status of virtual learning and its role in the higher education system in Jordan. It also considered previous research on online learning models locally, regionally, and in other countries. From the outset, the results pointed to the conclusion that, after experimenting with the online learning model, students expressed a moderate level of satisfaction with the new trend. However, the degree of satisfaction varied between two clusters of students with respect to their areas of specialization, i.e., "Arts \& Humanities" which scored higher percentages of satisfaction for their relative ease and convenience, compared to students enrolled in "Sciences" courses of practical nature and technical orientation such as lab-oriented courses in different branches of engineering, pharmacy, allied health sciences, and graphic and art design. At another level, our findings stressed the importance of providing a state-of-the-art technical infrastructure of powerful Internet connections and digital e-learning tools for an ideal online learning environment. In addition, the results focused on the relationship between students' economic and psychological conditions and their reactions to online learning.

Students' responses to the first construct in the questionnaire, namely "Technology Adequacy," showed that technology is a crucial element in the students' evaluation of the online learning experiment. Furthermore, the students' responses indicated that students equipped with a robust Internet connection and state-of-the-art technical support and e-learning tools show more interest and positive reactions to online learning. On the other hand, there was a positive correlation between students' responses to the fourth and fifth constructs of the questionnaire, namely "economic stressors" and "psychological stressors," and their unfavorable attitudes towards online learning. These findings are consistent with previous research outcomes, which draw a correlation between the students' low income and their poor academic success and progression through school 
(Jaggars \& Bailey, 2010; Sikhan, 2013). The question of the students' economic status and its effect on the students' academic performance and overall psychological well-being is a key factor in formulating some students' reactions to online learning in the Jordanian setting. As we indicated earlier, Jordan is a country with limited resources, which deprives some low-income students of securing the basic e-learning tools, Internet connection service, and other facilities which support online learning. Such a challenge adds to the students' social and psychological state of isolation brought by COVID-19's social distancing and closures (Ahmad S Haider \& Saleh Al-Salman, 2020).

Concerning research question 2, "Which type of courses (Arts and Humanities vs. Sciences) is better-suited for online teaching/learning than others which are less compatible with this model, and why?", students' responses showed that the course type, electronic content, and assessment methods affect students' choice of an online course against a face-to-face one. The students' reactions were corollary with their clustering into two major groups according to course type. The results suggested that Humanities courses are better suited for online teaching/ learning than Science courses. Students' responses are based on the assumption that the Arts \& Humanities courses are easier in terms of content and assessment. This assumption is based on students' reactions to some of the survey items (see items 3, 5, 6, 7, 8, 9, 13, 15, and 16), which confirm that Arts and Humanities courses are more compatible with online learning in terms of content and assessment. Moreover, the course objectives and learning outcomes of the "Arts and Humanities" courses are more compatible with e-learning than those of the "Science" courses, which are often of practical nature and need intensive student-instructor interactions, student-student discussions, and special assessment tools. Such findings are consistent with previous research (see Jaggars, 2012; Xu \& Jaggars, 2013).

Given the above, the results of construct 6 "Attitudes Towards the Future" showed that the students' reactions and attitudes to the online learning experiment in the higher education institutions in Jordan are influenced by different factors, including technology adequacy and instructional and assessment quality, in addition to the students' economic and psychological conditions. The findings reflected significant variation in the students' reactions based on their areas of specialization and the course type they are enrolled in, i.e., "Arts and Humanities" vs. "Sciences." Based on the students' responses to survey items 5, 6,7, 8, 9 about "Instructional Quality" and "Assessment Quality," and items 15 \& 16 of "Attitudes Towards the Future," it seems plausible that for students enrolled in the Arts and Humanities courses, frequent interaction with the instructors is not so crucial for them to achieve the intended learning outcomes compared to students enrolled in highly technical courses of medicine, dentistry, and engineering. The latter set of courses requires hands-on demonstration, practice, and intensive instructor-student interaction (Cadloff, 2020; Clinefelter \& Aslanian, 2015; Kebritchi et al., 2017; Xu \& Jaggars, 2013). For students enrolled in Science courses, frequent contact and guidance by the instructors may be a stronger priority. Besides, those courses require special assessment methods that are not always feasible through online testing.

Given the above, the recommendations and implications of the present study, with special emphasis on the Jordanian context, call for improving the infrastructure of online platforms. This requires providing students and instructors with enough training and Internet bundles while helping students secure digital e-learning tools. Equally important is enhancing students' social and psychological counseling and academic advising services. Taking such steps and measures will help adopt the "blended learning" system as a transitional stage before switching completely 
to online learning. In this context, we deem it fit to deliver university requirements and courses with large numbers of students through online learning platforms while teaching courses that are based on experimentation and practical applications on campus. In the same vein, the present study calls for integrating the online learning application systems such as MOOCs, among others, to keep abreast of international online learning techniques and models. For these recommendations to be effective, we deem it necessary to develop an up-to-date examination and assessment system compatible with online learning while taking into account that the exams of technical courses be conducted on campus.

These recommendations are consistent with the policy adopted by the Jordanian Ministry of Higher Education and Scientific Research. In an announcement to a local Jordanian TV Channel, Al-Mamlakah, dated August 17, 2020, the Minister of Higher Education and Scientific Research said that the Higher Education Council in Jordan has taken a decision to the effect that e-learning and distance learning will, from now on, be an essential part of the teaching-learning process. He added that the decision has been taken in view of the fact that the entire world is going in this direction, which contributes to developing the educational process in universities.

In sum, following the COVID-19 e-learning experiment in Jordan, online learning is no longer an option but a necessity. The same notion was expressed by Xu and Jaggars (2013, p. 26) who pointed out that "online coursework represents an indispensable strategy in postsecondary education, as it improves flexibility for both students and institutions." This suggests that online learning is here to stay; it will mark the beginning of a new era that will - most likelyrevolutionize and reshape the higher education paradigm in Jordan. Consequently, further research will be needed to explore ways and means of overcoming challenges and pursuing online learning trends in other parts of the world.

\section{Author Note}

Saleh Al-Salman

Email: salehalsalman2000@gmail.com

Applied Science Private University

Department of English Language and Translation

Amman, 11192

Jordan

https://orcid.org/0000-0002-0103-1330

Ahmad S Haider (corresponding author)

Email_Ah_haider86@yahoo.com

Applied Science Private University

Department of English Language and Translation

Amman, 11192

Jordan

http://orcid.org/0000-0002-7763-201X 


\section{References}

Abbad, M. M., Morris, D., \& De Nahlik, C. (2009). Looking under the bonnet: Factors affecting student adoption of e-learning systems in Jordan. International Review of Research in Open Distributed Learning, 10(2), 10-20. https://doi.org/10.19173/irrodl.v10i2.596

Al-Adwan, A., \& Smedley, J. (2012). Implementing e-learning in the Jordanian Higher Education System: Factors affecting impact. International Journal of Education Development using ICT, 8(1).

Al-Adwan, A. S., Al-Madadha, A., \& Zvirzdinaite, Z. (2018). Modeling students' readiness to adopt mobile learning in higher education: An empirical study. International Review of Research in Open Distributed Learning, 19(1), 220-241. https://doi.org/10.19173/irrodl.v19i1.3256

Al-Shboul, M., \& Alsmadi, I. (2010). Challenges of utilizing e-learning systems in public universities in Jordan. International Journal of Emerging Technologies in Learning, 5(2), 4-10. https://doi.org/10.3991/ijet.v5i2.1147

Al-Shboul, M., Rababah, O., Al-Saideh, M., Betawi, I., \& Jabbar, S. (2013). A vision to improve e-Learning at the University of Jordan. World Applied Sciences Journal, 21(6), 902-914.

Alkhawaja, M. I., \& Abd Halim, M. S. B. (2019). Challenges of e-learning system adoption in Jordan higher education. International Journal of Academic Research in Business Social Sciences, 9(9), 487-494. https://doi.org/10.6007/ijarbss/v9-i9/6317

Almarabeh, T. (2014). Students' perceptions of e-learning at the University of Jordan. International Journal of Emerging Technologies in Learning, 9(3), 31-35. https://doi.org/10.3991/ijet.v9i3.3347

Almarabeh, T., Mohammad, H., Yousef, R., \& Majdalawi, Y. K. (2014). The University of Jordan e-learning platform: State, students' acceptance and challenges. Journal of Software Engineering Applications, 7(12), 999. https://doi.org/10.4236/jsea.2014.712087

Badran, A. (2014). New trends in higher education in Jordan 2014. Education, Economic and Development. 4th Arab-Turkish Congress of Social Sciences. Arab Thought Forum. Amman-Jordan.

Bolliger, D. U., \& Martin, F. (2018). Instructor and student perceptions of online student engagement strategies. Distance Education, 39(4), 568-583. https://doi.org/10.1080/01587919.2018.1520041

Burgess, S., \& Sievertsen, H. H. (2020). Schools, skills, and learning: The impact of COVID-19 on education. VoxEu. org, 1 .

Cadloff, E. (2020). The big transition begins as faculty switch to online learning in response to COVID-19. University Affairs. https://www.universityaffairs.ca/news/news-article/thebig-experiment-begins-as-faculty-switch-to-online-learning-in-response-to-covid-19/

Canals, L., \& Al-Rawashdeh, A. (2019). Teacher training and teachers' attitudes towards educational technology in the deployment of online English language courses in Jordan. 32(7), 639-664. https://doi.org/10.1080/09588221.2018.1531033 
Clinefelter, D. L., \& Aslanian, C. B. (2015). Online college students 2015: Comprehensive data on demands and preferences. The Learning House, Inc.

Cronbach, L. J. (1951). Coefficient alpha and the internal structure of tests. psychometrika, 16(3), 297-334. https://doi.org/10.1007/bf02310555

German Academic Exchange Service (DAAD). (2020). COVID-19 Impact on International Higher Education: Studies \& Forecasts. https://www.daad.de/en/information-servicesfor-higher-education-institutions/centre-of-competence/covid-19-impact-on-internationalhigher-education-studies-and-forecasts/.

Haider, A. S., \& Al-Salman, S. (2020). Covid-19's impact on the higher education system in Jordan: Advantages, challenges, and suggestions. Humanities and Social Sciences Reviews, 8(4), 1418-1428. https://doi.org/10.18510/hssr.2020.84131

Haider, A. S., \& Al-Salman, S. (2020). Dataset of Jordanian university students' psychological health impacted by using e-learning tools during COVID-19. Data in Brief, 32. https://doi.org/10.1016/j.dib.2020.106104

Human Rights Watch. (1999). The Internet In the Middle East and North Africa: A Cautious Start. https://www.hrw.org/legacy/advocacy/internet/mena/int-mena.htm

International Association of Universities. (2020). The impact of COVID-19 on higher education worldwide Resources for Higher Education Institutions. https://www.iauaiu.net/IMG/pdf/covid-19_and_he_resources.pdf

Jaggars, S. S. (2012). Beyond flexibility: Why students choose online and face-to-face courses in community college. American Educational Research Association Annual Meeting, Vancouver, Canada.

Jaggars, S. S., \& Bailey, T. R. (2010). Effectiveness of fully online courses for college students: Response to a Department of Education meta-analysis. https://ccrc.tc.columbia.edu/media/k2/attachments/effectiveness-online-response-metaanalysis.pdf

Kebritchi, M., Lipschuetz, A., \& Santiague, L. (2017). Issues and challenges for teaching successful online courses in higher education: A literature review. Journal of Educational Technology Systems, 46(1), 4-29. https://doi.org/10.1177/0047239516661713

Kendal, M., \& Stuart, A. (1973). The Advanced Theory of Statistics: Inference and Relationship (Vol. 2). Hafner Publishing Company.

Liaw, S.-S., Huang, H.-M., \& Chen, G.-D. (2007). Surveying instructor and learner attitudes toward e-learning. Computers Education, 49(4), 1066-1080. https://doi.org/10.1016/j.compedu.2006.01.001

Majadlawi, Y., Almarabeh, T., \& Mohammad, H. (2014). Factors affecting students' usage of learning management system at The University of Jordan. Life Science Journal, 11(6), 666-671.

Ministry of Higher Education and Scientific Research (MoHESR). (2020). Private Jordanian universities. http://www.mohe.gov.jo/en/pages/PrivateUniversities.aspx

Nunnally, J. C. (1978). Psychometric Theory: 2d Ed. McGraw-Hill. 
Ozkan, S., \& Koseler, R. (2009). Multi-dimensional students' evaluation of e-learning systems in the higher education context: An empirical investigation. Computers Education, 53(4), 1285-1296. https://doi.org/10.1016/j.compedu.2009.06.011

Roach, V., \& Lemasters, L. (2006). Satisfaction with online learning: A comparative descriptive study. Journal of Interactive Online Learning, 5(3), 317-332.

Selim, H. M. (2007). Critical success factors for e-learning acceptance: Confirmatory factor models. Computers Education, 49(2), 396-413. https://doi.org/10.1016/j.compedu.2005.09.004

Sikhan, K. (2013). Low-income students six times more likely to drop out of high school. World Socialist website.

UNESCO. (2020). Education: From disruption to recovery. COVID-19: Global Education Coalition. https://en.unesco.org/covid19/educationresponse

Upoalkpajor, J.-L. N., \& Upoalkpajor, C. B. (2020). The Impact of COVID-19 on Education in Ghana. Asian Journal of Education Social Studies, 9(1), 23-33. https://doi.org/10.9734/ajess/2020/v9i130238

Wimpenny, K., Adefila, A., \& DeWinter, A. (2018). Jordan Opportunity for Virtual Innovative Teaching and Learning: A Needs Analysis Report Contextualising the State of the Art in International Online Teaching and Learning, with Particular Attention to the Jordanian Case. Coventry University.

Xu, D., \& Jaggars, S. S. (2013). Adaptability to online learning: Differences across types of students and academic subject areas. CCRC Working Paper No. 54, 1-26. 


\section{Appendix A: Questionnaire}

\section{Demographic Information:}

Gender: Male: __ Female:

\section{Specialization:}

Humanities: (Faculty of Arts, Faculty of Business, Faculty of Sharia, Faculty of Educational Sciences, Faculty of Law, Faculty of Physical Education, Faculty of Foreign Languages, Faculty of Archeology and Tourism)

Science: (Faculty of Science, Faculty of Agriculture, Faculty of Engineering, Faculty of Information Technology, Faculty of Pharmacy, Faculty of Nursing, Faculty of Dentistry, Faculty of Medicine)

\section{Dear Student:}

This research tool is designed to elicit students' responses about the effectiveness of the e-learning experiment resulting from the COVID-19 outbreak. The researchers assure you that your responses to the questionnaire will be used only for research purposes.

Please respond to each of the following questions as indicated against each:

Thank you!

\begin{tabular}{|c|c|c|c|c|c|c|}
\hline No. & Item & \multicolumn{5}{|l|}{ Response } \\
\hline $\mathbf{A}$ & \multicolumn{6}{|l|}{ Technology Adequacy } \\
\hline & & $\begin{array}{l}\text { Strongly } \\
\text { Agree }\end{array}$ & Agree & Uncertain & Disagree & $\begin{array}{l}\text { Strongly } \\
\text { Disagree }\end{array}$ \\
\hline 1 & $\begin{array}{l}\text { The digital tools (mobile, } \\
\text { laptop, or iPad) I use in e- } \\
\text { learning are of high } \\
\text { quality. }\end{array}$ & & & & & \\
\hline 2 & $\begin{array}{l}\text { I faced some technical } \\
\text { problems in the online } \\
\text { lectures last semester due } \\
\text { to Internet connection } \\
\text { issues. }\end{array}$ & & & & & \\
\hline 3 & $\begin{array}{l}\text { I encountered technical } \\
\text { problems while submitting } \\
\text { exams electronically. }\end{array}$ & & & & & \\
\hline
\end{tabular}




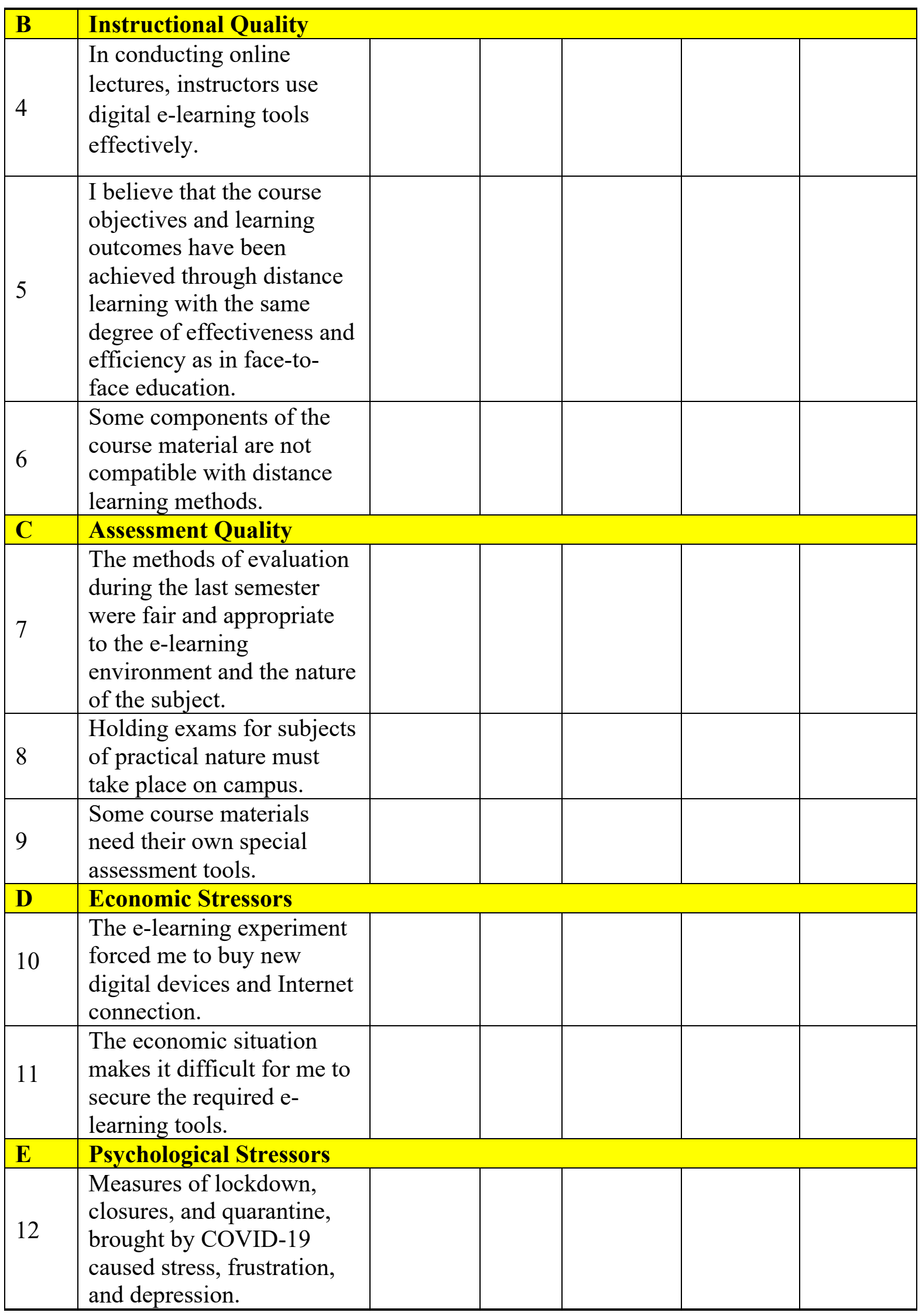




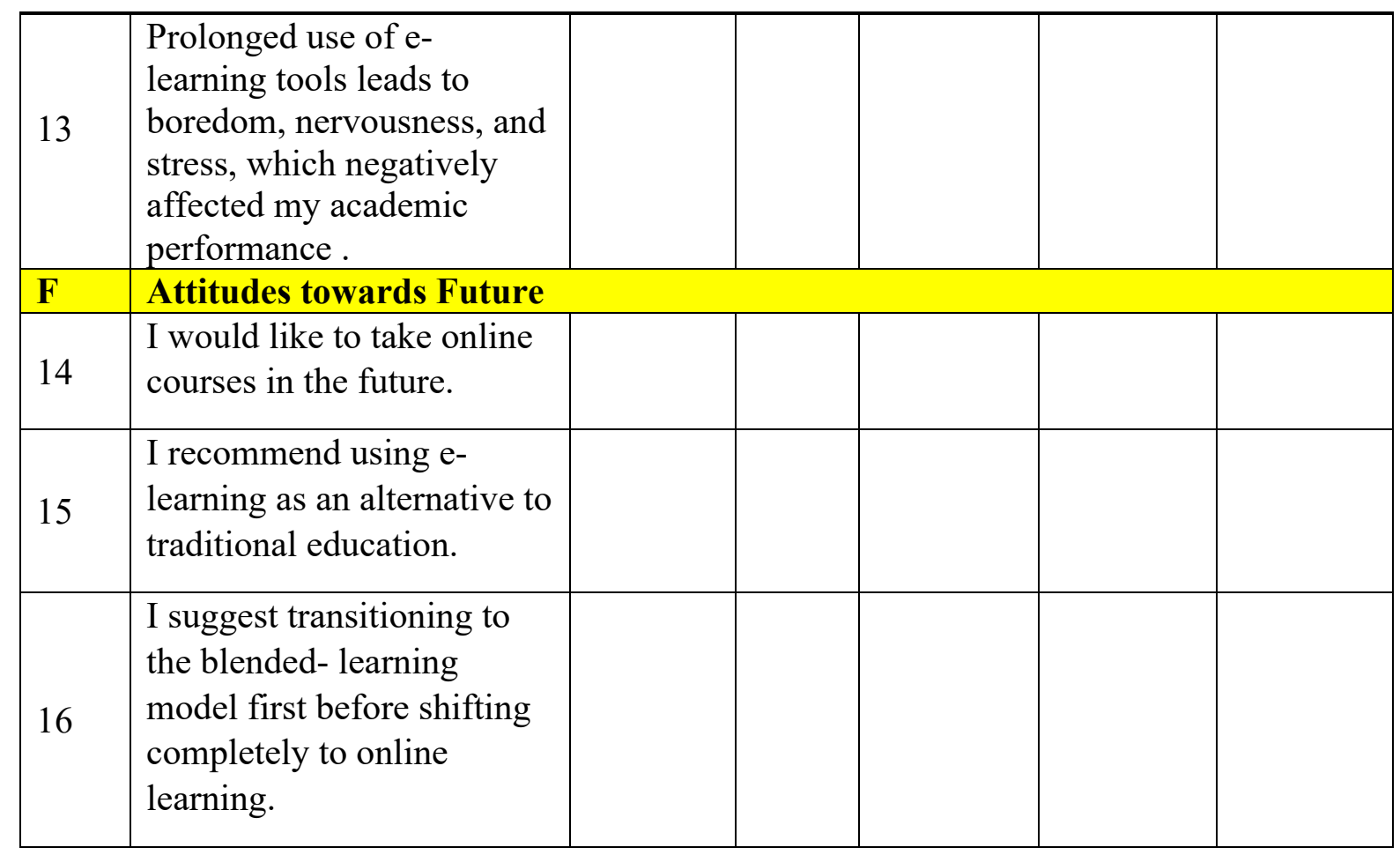

